\title{
Friction Stir Welding of High Phosphorus Weathering Steel \\ - Weldabilities, Microstructural Evolution and Mechanical Properties
}

\author{
Takumi KawaKubo ${ }^{1)}$, Tomoya Nagira $^{2)}$, Kohsaku Ushioda ${ }^{1)}$ and Hidetoshi FujiI ${ }^{1 *}$ \\ 1) Joining and Welding Research Institute, Osaka University \\ 2) Joining and Welding Research Institute, Osaka University, now National Institute for Materials Science
}

Abstract: Phosphorus (P) addition is expected to simultaneously increase the strength and corrosion resistance of weathering steels. However, P causes solidification cracking in the fusion welding process and reduces the toughness of steel. To avoid these problems, the P content of weldable SMA490AW weathering steel is currently limited to below 0.035 mass $\%$. High P steels which are impossible to be joined by the fusion welding process, can be joined by a solid-state joining process, friction stir welding (FSW). Because the stir zone obtained by FSW contained very fine grains, its toughness was expected to improve. This study applies FSW to high-P weathering steels and examines the weldability of the product. The microstructural evolution and mechanical properties of the stir zone were investigated at different welding temperatures. The macroscopic cross-sectional observations of the FSW joints revealed crack-free structures even in steel containing 0.3 mass $\%$ P. Moreover, FSW significantly refined the grain structure in the stir zone. Consequently, the ductile-to-brittle transition temperature of the stir zone was approximately $150^{\circ} \mathrm{C}$ lower in the steel containing 0.3 mass $\% \mathrm{P}$ and welded below $A_{1}$ (average grain size $=2.5 \mu \mathrm{m}$ ) than in the base material (average grain size $=23 \mu \mathrm{m}$ ). It appears that the grain refinement by FSW overcomes the embrittlement caused by excessive P content.

Keywords: friction stir welding; weathering steel; phosphorus; microstructure; mechanical property; ductile-to-brittle transition temperature; stressstrain curve.

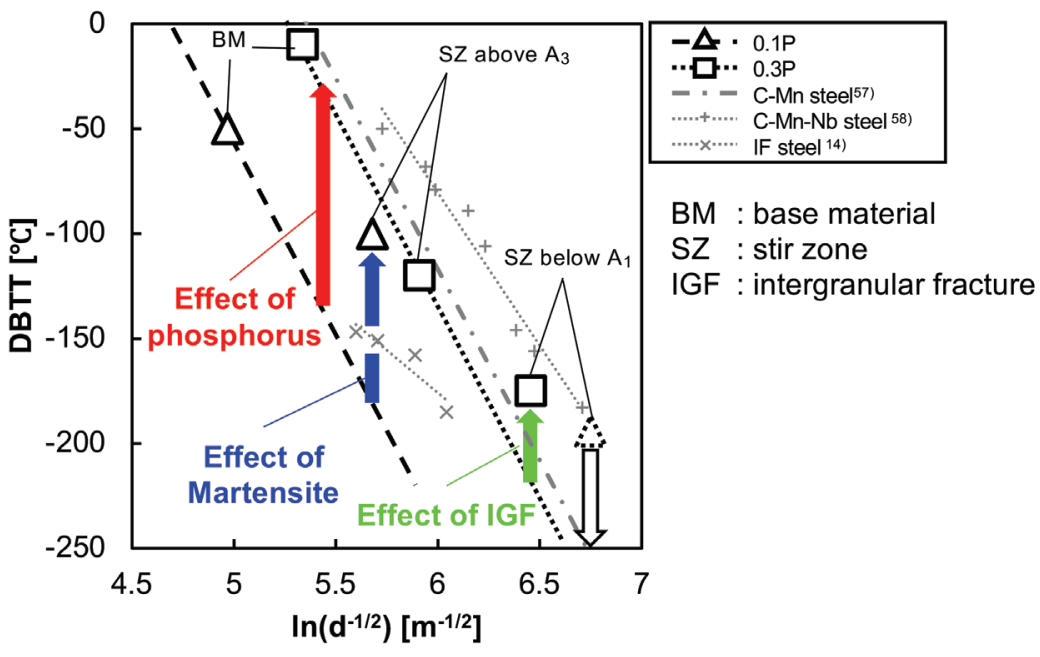




\title{
高 $P$ 耐候性鋼の摩擦攪拌接合 一その接合性, 組織の発達および機械的特性一
}

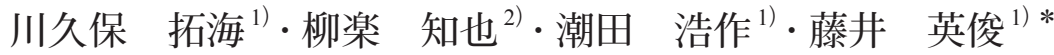 \\ Friction Stir Welding of High Phosphorus Weathering Steel \\ - Weldabilities, Microstructural Evolution and Mechanical Properties \\ Takumi Kawakubo Tomoya Nagira, Kohsaku Ushioda, Hidetoshi FunII
}

\section{1. 緒言}

耐候性鋼は少量の $\mathrm{Cu}, \mathrm{P}, \mathrm{Cr}, \mathrm{Ni}$ などの元素を含む低合 金鋼で，大気中で裸使用した時に表面に緻密な保護性の高 い錆層を形成し，優れた耐大気腐食性を示す。塗装なしで 長期的な耐久性を確保でき, ライフサイクルコストの低減 が可能であることから, 橋梁を中心に広く適用されている。

耐候性鋼において, Pは安価に耐候性および強度を向上 させることができる魅力的な元素である。Pの添加により 耐候性が向上し ${ }^{1-6)}$ ，少なくとも $0.5 \mathrm{mass} \%$ までは，P量の 増加に伴い大気暴露環境下での腐食量が減少することが報 告されている ${ }^{1)}$ 。また, $\mathrm{P}$ は少量の添加で効果的に強度を高 めることができる ${ }^{7,8)}$ 。一方ではPは母材の勒性を低下させ たり ${ }^{9-16)}$, 溶接性を著しく悪化させる ${ }^{17-21)}$ 問題がある。

$\mathrm{P}$ の溶融溶接性への悪影響については, 凝固温度幅を大 きく拡大するため高温割れの一つである凝固割れを誘発す るためと考えられている ${ }^{21)}$ 。そのため, 既存の溶融溶接を 想定した耐候性鋼であるSMA490AW ${ }^{22}$ では, P量は 0.035 mass \%以下に制限されている。一方, 而候性は優れるが溶 融溶接が不可能な非溶接耐候性鋼として P 量が 0.1 mass \% 添加された SPA-H ${ }^{23)}$ も存在する。

$\mathrm{P}$ に起因する溶接性の課題を克服するために, 摩擦攪汼 接合法 (Friction Stir Welding: FSW) の適用が有効であると 考えられる。FSW は, 金属の融点以下の温度で接合する固 相接合プロセスである。主にアルミニウム合金で実用化さ れているプロセスであるが24-27), 鉄鋼材料への適用を目指 した研究も盛んに行われている ${ }^{28-34)}$.FSW は, 接合中に凝 固を伴わないため溶接割れを抑制できると考えられ，Pに おける溶接性の課題の克服が期待される。

また，Pの勒性への悪影響については，Pが粒界に偏析 して勒性を悪化させることが多数報告されている ${ }^{9-15)}$ 。そ の理由として, Yamaguchi ${ }^{15)}$ はPの粒界偏析濃度の増加が
粒界凝集エネルギーを減少させ，粒界破壊応力が低下する からであると説明した。一方で, Suzuki ら ${ }^{9)}$ はCを約 0.01 mass $\%$ 以上添加すると, 粒界にCが先に偏析するためPの 粒界偏析量が減少し, 粒界破壊が抑制されることを示し た。而候性鋼の C 量は約 0.1 mass\%であり, また $\mathrm{P}$ 量の上限 の設定や粒界偏析を低減するためのプロセス条件を制御す ることにより，粒界破壊は起こらないと考えられる。しか し，この場合においても，Pは大きな固溶強化により転位 のすべりを阻害するため, $\mathrm{P}$ 量の増加はへき開破壊を生じ させ，勒性の低下を招くことが予想される。

勒性改善の方法として, 結晶粒の微細化が良く知られて いる ${ }^{35-39)}$ 。例えば, フェライト組織において, 結晶粒径を $20 \mu \mathrm{m}$ から $1 \mu \mathrm{m}$ に制御することにより, 延性脆性遷移温度 (ductile-brittle transition temperature: DBTT) が $282^{\circ} \mathrm{C}$ 低温側 にシフトすることが報告されている ${ }^{35)}$ 。結晶粒超微細化の 手法には, 従来の制御圧延技術 ${ }^{36,37)}$ に加え, ECAP (EqualChannel Angular Pressing) 法 ${ }^{38)}$, ARB (Accumulative RollBonding) 法 ${ }^{14,39)}$ などの強加工と熱処理の組み合わせが提案 されている。FSWは, 接合中にきわめて大きいせん断加工 が導入され, また発熱が生じるため, 動的再結晶が生じ著 しく細粒化した組織が得られることが知られている ${ }^{31,32)} 。$ したがって, 高 $\mathrm{P}$ 鋼の攪拌部は組織微細化による勒性の向 上が期待される。

本研究では, P 量を 0.1-0.3 mass\%の範囲で添加した溶融 溶接が不可能な耐候性鋼を作製し, FSWによる接合性を検 証した。加えて, 母材およびFSW 攪拌部における微細組織 および機械的特性について評価し, 機械的特性に及ぼす P 量および結晶粒微細化の影響について調査することを目的 とした。 


\section{2. 実験方法}

Table 1 に本研究で用いた試料の合金組成を示す。 SMA490AW は既存の耐候性鋼であり，溶接構造用である ためPの添加量が 0.01 mass\%程度に抑えられている。 $0.1 \mathrm{P}$ 材および $0.3 \mathrm{P}$ 材は実験室で作製した高 $\mathrm{P}$ 添加の耐候性鋼で ある。これらの試料は高周波溶解により作製した。原料に は, 電解鉄 (99.9\%, 小片状), 純カーボン (99.9\%, 粉末状), 純シリコン $(99.9 \%)$, 電解マンガン $(99.9 \%$, 薄片状), フェ ロリン (Fe-20 mass\%P, 塊状)，純銅 (99.99\%，粒状）および 電解クロム $(99 \%$, 薄片状) を用いた。これらの原料をアル ミナ製耐火るつぼ投入し, 高周波溶解装置を用いて溶製 した。溶解は 0.5 気圧のアルゴン雲囲気中で行った。得られ た $350 \mathrm{~g}$ のインゴットは, 最終凝固部を切除し，最終的に $\phi$ $30 \times 40 \mathrm{~mm}$ の形状とした。得られたインゴットに対して, $1000^{\circ} \mathrm{C}$ の熱間圧延を繰り返して9回行い, 3.5-4.0 mmの厚 さとした。最後に $1000^{\circ} \mathrm{C}, 10 \mathrm{~min}$, 空冷の条件で焼きなら

Table 1. Chemical composition of base materials investigated in this study.

\begin{tabular}{cccccccccc}
\hline & $\mathrm{C}$ & $\mathrm{Si}$ & $\mathrm{Mn}$ & $\mathrm{P}$ & $\mathrm{S}$ & $\mathrm{Cu}$ & $\mathrm{Ni}$ & $\mathrm{Cr}$ & $\mathrm{Al}$ \\
\hline SMA490AW & 0.12 & 0.2 & 1.14 & 0.01 & 0.002 & 0.32 & 0.10 & 0.48 & - \\
\hline $0.1 \mathrm{P}$ & 0.10 & 0.51 & 0.09 & 0.10 & $<0.001$ & 0.49 & 0.01 & 0.39 & 0.03 \\
\hline $0.3 \mathrm{P}$ & 0.08 & 0.5 & 0.09 & 0.27 & $<0.001$ & 0.49 & 0.01 & 0.4 & 0.02 \\
\hline
\end{tabular}

(a)

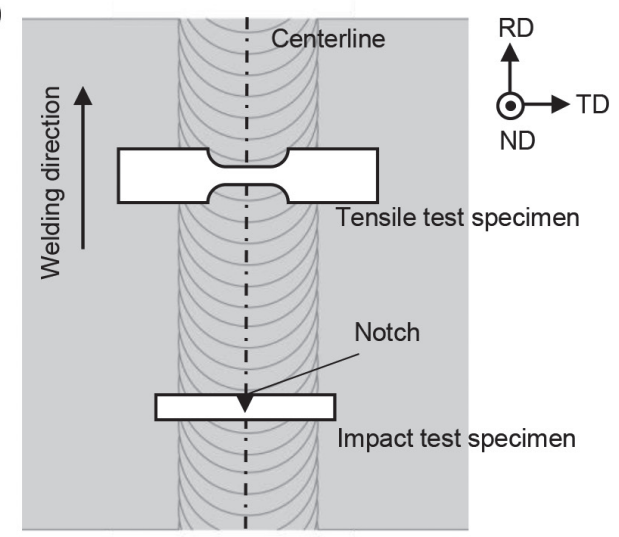

(b)

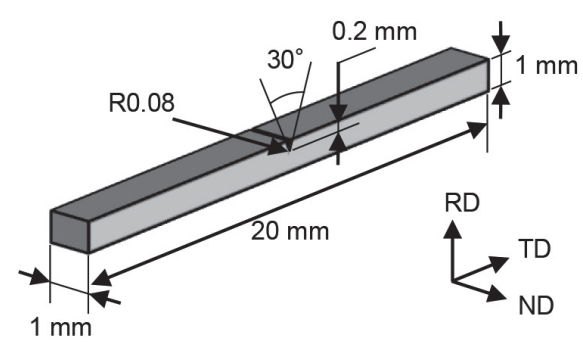

Fig. 1. Schematic of (a) sampling position of tensile test specimen and impact test specimen and (b) shape of impact test specimen.
し熱処理を行った。表面の酸化膜を研削して除去し, $3 \mathrm{~mm}$ 厚のプレートを得た。なお，第3章で述べるように, $1000^{\circ} \mathrm{C}$ は $0.1 \mathrm{P}$ およひ $0.3 \mathrm{P} の A_{\mathrm{e} 3}$ 点より高い, オーステナイト域で の温度である。

作製したプレートに対してFSWを行った。ツールの材 質はタングステンカーバイド（WC）を主体とする超硬合 金製であり，形状はプローブをネジ加工していない円柱状 である。ツールの寸法については，ショルダー直径 $15 \mathrm{~mm}$, プローブ直径 $6 \mathrm{~mm}$ ，プローブ長さ $2.9 \mathrm{~mm}$ とした。接合条 件は接合温度がそれぞれ $A_{3}$ 点以上 (回転速度: $400 \mathrm{rpm}$, 接 合速度: $150 \mathrm{~mm} / \mathrm{min}$ ) と $A_{1}$ 点以下 (回転速度: $80 \mathrm{rpm}$, 接合 速度： $150 \mathrm{~mm} / \mathrm{min}$ ) となるように 2 種類の条件を用いた。熱 電対を用いて攪拌部の裏側の温度履歴を測定した。

得られた接合部の接合方向に対して垂直な断面を放電 加工により切り出し, その断面に打いて微細組織観察お よびビッカース硬さ試験を行った。微細組織の評価には, SEM，EBSD（JEOL製：JSM-7001FA）を用いた。SEM観察

(a)

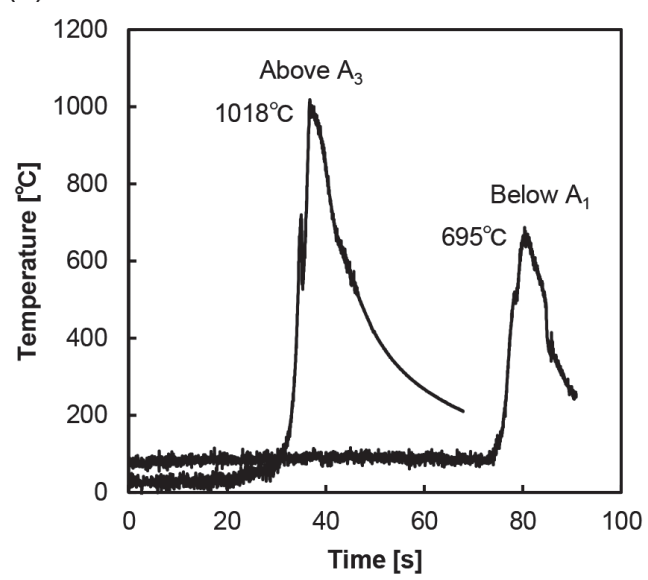

(b)

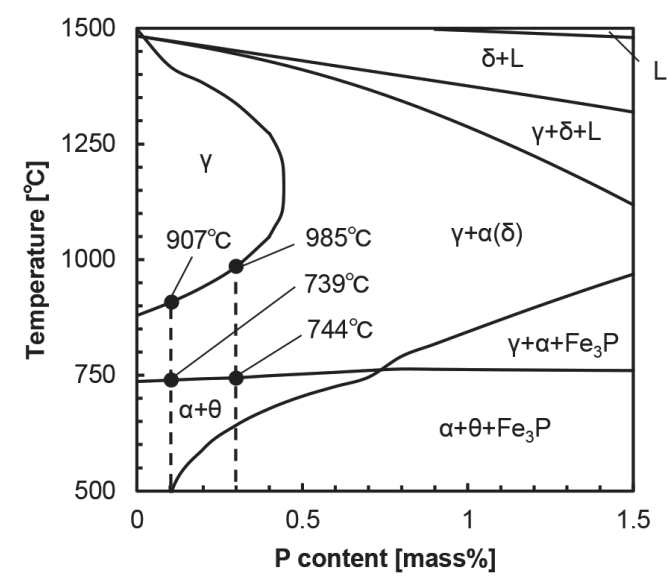

Fig. 2. (a) Heat cycles obtained by thermocouples located on the bottom surface at the centerline for SMA490AW; (b) $\mathrm{Fe}(0.1 \mathrm{C}-0.5 \mathrm{Si}-0.1 \mathrm{Mn}-0.5 \mathrm{Cu}-0.4 \mathrm{Cr})-\mathrm{P}$ pseudo-binary phase diagram evaluated by thermodynamic calculation, using the Thermo-Calc. TCFE9. 
用の試料は，エメリー紙\#400-4000を用いた湿式研磨，バ フ研磨を行った後, $4 \%$ ナイタール液を用いて常温で約 5 秒 間エッチングして準備した。EBSD観察用の試料は, 湿式 研磨, バフ研磨後, 過酸化水素-酢酸混合電解液 $\left(\mathrm{HClO}_{4}\right.$ : $\left.\mathrm{CH}_{3} \mathrm{COOH}=1: 9\right)$ 中で電圧 $15 \mathrm{~V}$ と設定して, 15 秒間の電 解研磨を行い準備した。ビッカース硬さ試験は，接合部の 断面に対して, 荷重を $2.94 \mathrm{~N}$, 保持時間を $15 \mathrm{~s}$ として行っ た。また，母材，攪拌部のそれぞれの機械的特性を評価す るため,引張試験と衝撃試験を行った。引張試験は，平行 部長さ $5 \mathrm{~mm}$, 幅 $2 \mathrm{~mm}$, 厚さ $2 \mathrm{~mm}$ の試験片を用いて, ひず み速度は $5.0 \times 10^{-3} \mathrm{~s}^{-1}$ として行った。なお Fig.1 (a) に示 すように，平行部の方向は接合方向と垂直な方向であり， 攪拌部が平行部に入るように設定した。また，ひずみ測定 にはDigital Image Correlation (DIC) 法を用いた。公称ひず みは, 初期の評点間距離 $4.5 \mathrm{~mm}$ の引張変形中の変化から評 価した。衝撃試験は, 計装化微小シャルピー衝撃試験機 (タ ナカ，MIT-D05KJ型）を用いて，長さ，幅，厚さがそれぞれ $20 \mathrm{~mm}, 1 \mathrm{~mm}, 1 \mathrm{~mm}$ の特殊小型試験片 (Fig.1 (b)) で評価 した。接合方向に深さ $0.2 \mathrm{~mm}$, 先端の Rが $0.08 \mathrm{~mm}$ のノッ チを導入した。試料の採取場所は，攪找部についてはノッ チが接合中心部にくるように，母材についてはノッチが接 合中心から $10 \mathrm{~mm}$ 以上離れた位置にくるような場所とし た。またDBTTは, 試験片サイズが微小であることによる
影響が少ないと考えられる，完全に脆性破壊する温度域と 延性一脆性遷移温度域の境界の温度とした。

\section{3. 実験結果}

\section{$3 \cdot 1$ 接合温度および接合体の健全性}

Fig.2 (a) に各接合条件における接合中の温度履歴を 示す。また, Fig.2 (b) にThermo-calc.により作成した Fe (0.1C-0.5Si-0.1Mn-0.5Cu-0.4Cr) -Pの状態図を示す。既に述 べた $A_{3}$ 点以上および $A_{1}$ 点以下の FSW 条件での最高到達温

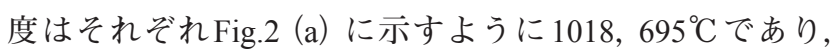
どちらの試料に打いてもそれぞれの条件が $A_{\mathrm{e} 3}$ 点以上また は $A_{\mathrm{e} 1}$ 点以下であることが確認できる。

Fig.3に各試料をそれぞれの接合条件でFSWした後の， FSW 断面マクロ写真を示す。いずれの接合部も欠陥のない 健全な接合部であることがわかる。

\section{$3 \cdot 2$ 母材およびFSW 攪拌部の組織}

Fig.4に各試料の母材と覮找部におけるSEM像を示す。 母材は各試料ともフェライトとパーライトから構成され る。フェライト粒径は，0.1P材で $49 \mu \mathrm{m}, 0.3 \mathrm{P}$ 材で $23 \mu \mathrm{m}$ で ある。 $A_{3}$ 点以上の攪拌部は各試料とも, フェライトとパー ライトに加えて, ベイナイトやマルテンサイトなどの低温 変態生成物も存在する。これは, 接合後の冷却中にオース

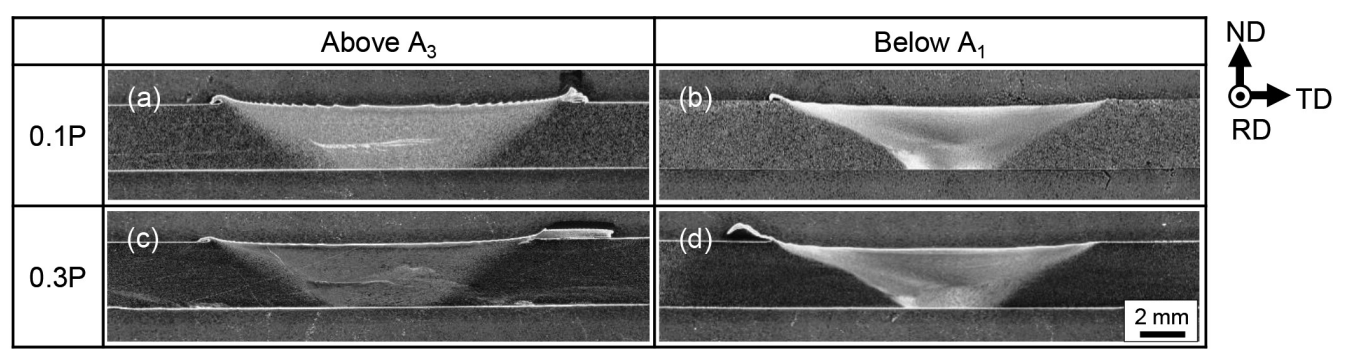

Fig. 3. Photographs showing the cross section of FSW joints for $0.1 \mathrm{P}$ and $0.3 \mathrm{P}$ samples under the two different FSW conditions.
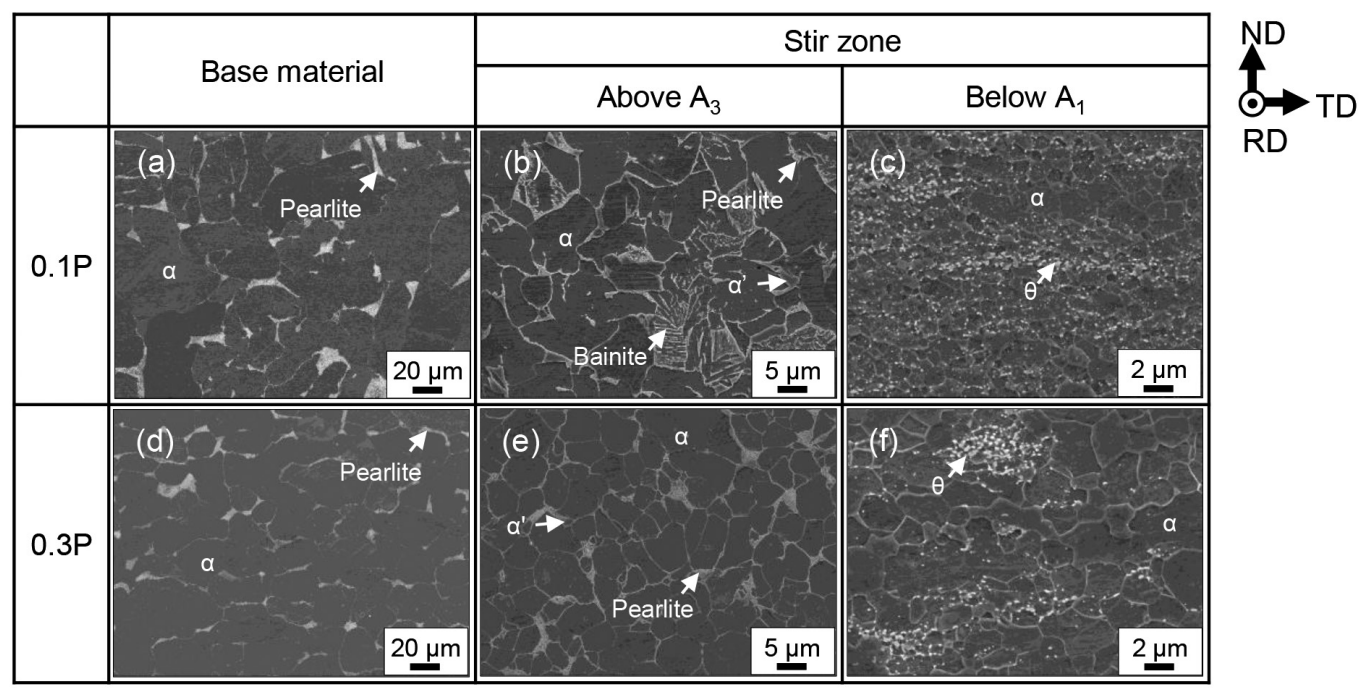

Fig. 4. SEM microstructures of base material and stir zones under above $A_{3}$ and below $A_{1}$ conditions for $0.1 \mathrm{P}$ and $0.3 \mathrm{P}$ samples. 
テナイトからの変態で形成されることに起因する。 $\mathrm{P}$ 量の 増加に伴い低温変態生成物の量は減少する傾向を示した。 また，フェライト粒径は，0.1P材で $12 \mu \mathrm{m}, 0.3 \mathrm{P}$ 材で $7.3 \mu \mathrm{m}$ に微細化した。 $A_{1}$ 点以下の覮拌部は, 各試料ともフェライ 卜と微細な球状セメンタイトから構成される。フェライト 粒径は, $0.1 \mathrm{P}$ 材で $1.4 \mu \mathrm{m}, 0.3 \mathrm{P}$ 材で $2.5 \mu \mathrm{m}$ であり, 予想に 反して0.3P材の方が粒径が大きい。また，母材と比較して， 覮拌部では両材ともに著しく微細化したことは特筆され る。微細なセメンタイトサイズは, 0.1P材, 0.3P材ともに 大きいものでも $0.5 \mu \mathrm{m}$ 程度で, 小さいものでは $0.1 \mu \mathrm{m}$ 以下 である。

Fig.5には, 各試料の母材と観挥部におけるフェライト粒 を正確に把握するために, EBSD の Inverse Pole Figure (IPF) マップを基に得られた，方位差 $15^{\circ}$ 以上の高角粒界からな るフェライト組織を示す。各試料とも攂找部のフェライト の結晶粒は，接合中のオーステナイト域あるいはフェライ 卜域での動的再結晶により，母材と比べて微細であり，特 に接合温度が低い $A_{1}$ 点以下の攪挥部の結晶粒は $A_{3}$ 点以上 のそれと比べてさらに微細である特徵がある。また, $A_{1}$ 点 以下の䚓找部における結晶粒は, $0.1 \mathrm{P}$ 材では平均結晶粒径 が約 $1.4 \mu \mathrm{m}$ の比較的均一な微細粒を示すが，0.3P材では約 $2.6 \mu \mathrm{m}$ のBimodal組織を示すことは特筆される。

Fig.6に各試料の $A_{1}$ 点以下の攂挥部における粒度分布を 示す。破線は平均粒径である。0.1P材では全ての結晶粒の 粒径が $4 \mu \mathrm{m}$ 以下であるのに対して，0.3P材では，粒径が約 $4 \mu \mathrm{m}$ においてもピークが存在し (図中矢印) , 4 7 $\mu \mathrm{m}$ の範 囲の粒も多く分布しており，Bimodal的な粒度分布が認め られた。
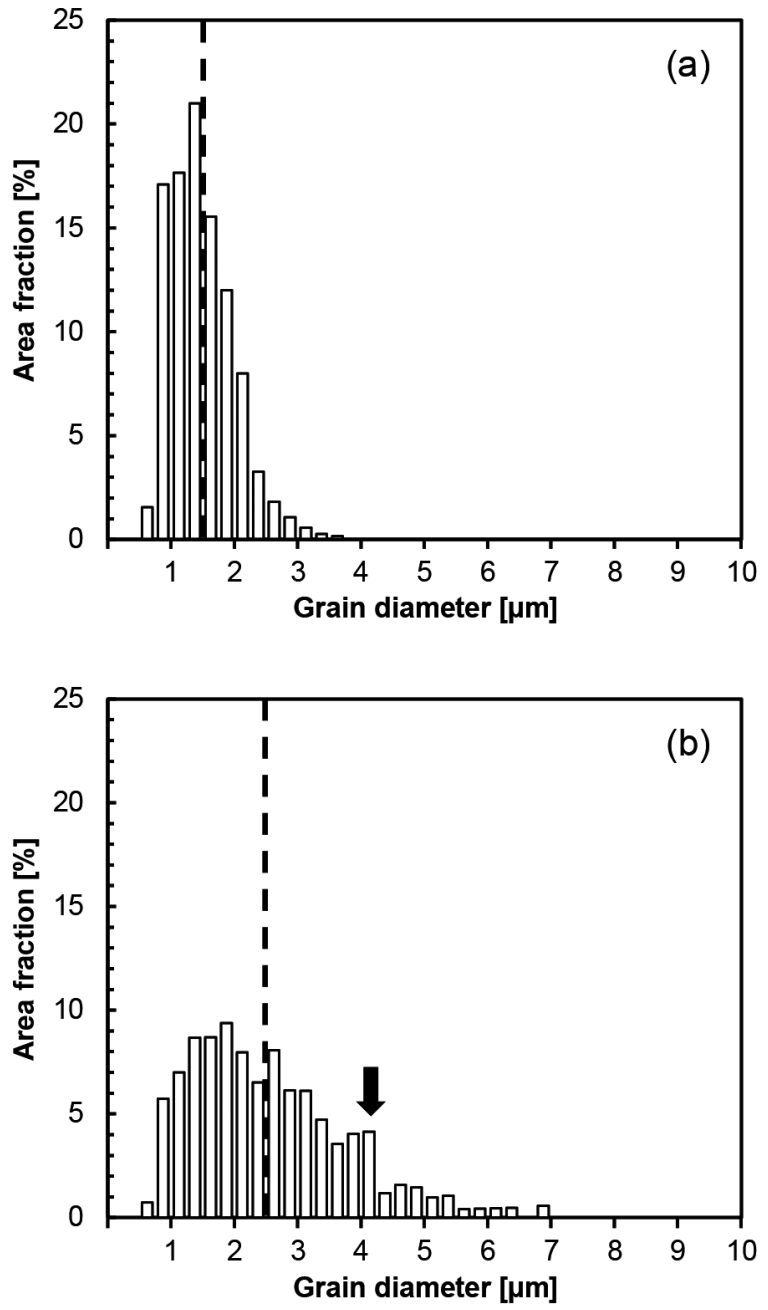

Fig. 6. Area fraction distribution of the grain sizes in the stir zone under below $A_{1}$ condition for (a) $0.1 \mathrm{P}$ and (b) $0.3 \mathrm{P}$ samples.

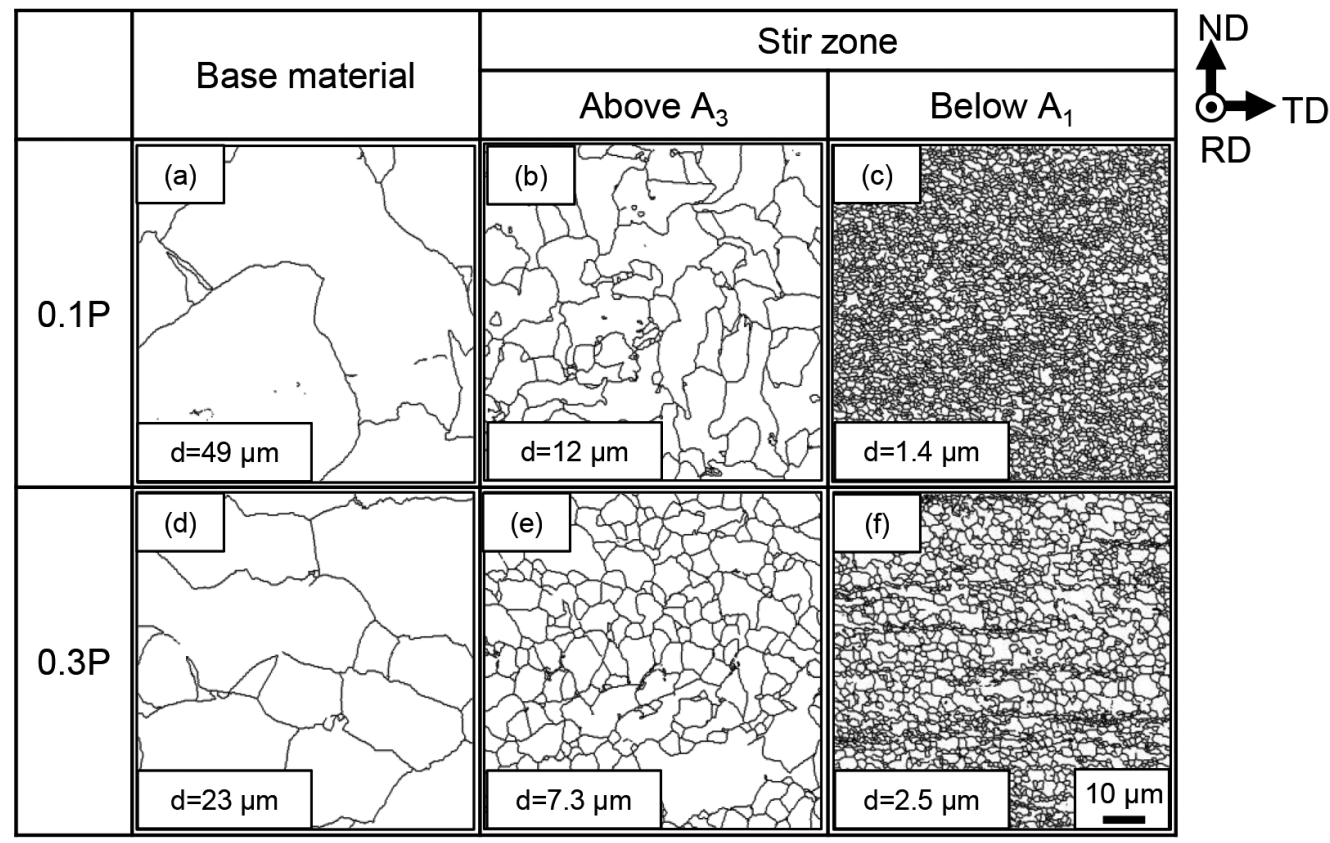

Fig. 5. EBSD map showing grain boundaries of base materials and stir zones under above $\mathrm{A}_{3}$ and below $\mathrm{A}_{1}$ conditions for $0.1 \mathrm{P}$ and $0.3 \mathrm{P}$ samples. 

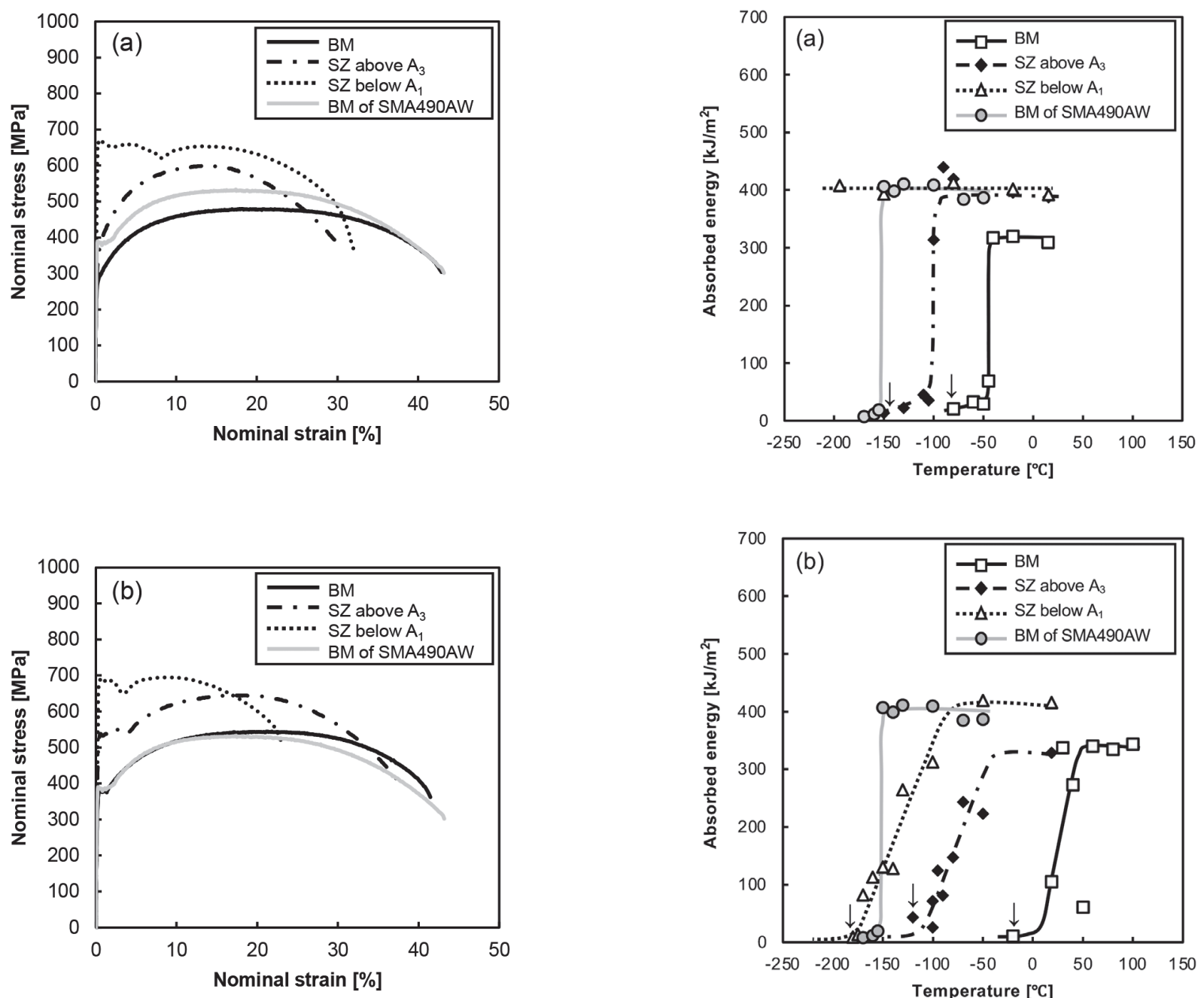

Fig. 7. Nominal stress-nominal strain curves of base materials and stir zones under above $A_{3}$ and below $A_{1}$ conditions for (a) $0.1 \mathrm{P}$ and (b) $0.3 \mathrm{P}$ samples, and the base material for SMA490AW for comparison.

Fig. 8. Temperature dependence of absorbed impact energy of base materials and stir zones under above $A_{3}$ and below $A_{1}$ conditions for (a) $0.1 \mathrm{P}$ and (b) $0.3 \mathrm{P}$ samples, and the base material for SMA490AW for comparison.

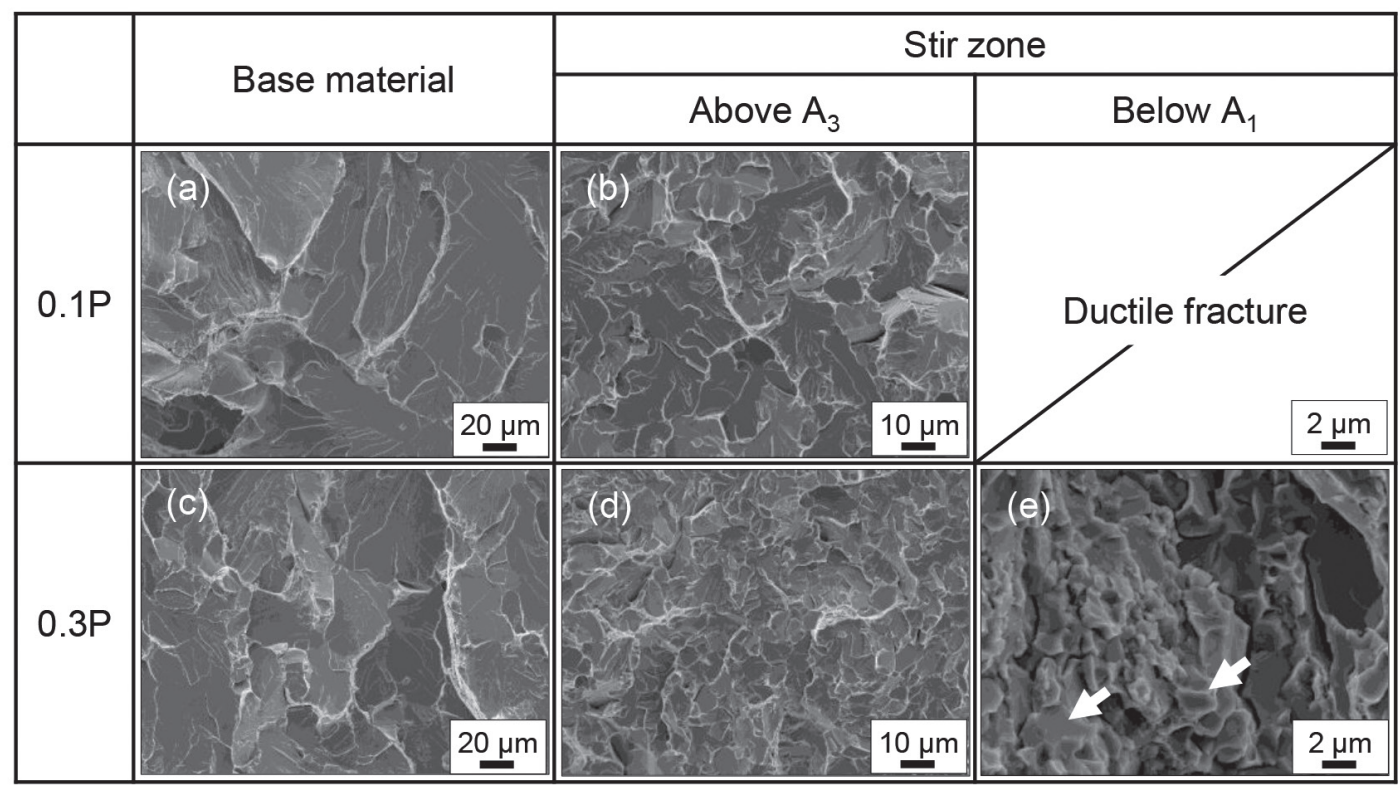

Fig. 9. SEM images showing the brittle fracture surfaces of base materials and stir zones under above $A_{3}$ and below $A_{1}$ conditions for $0.1 \mathrm{P}$ and $0.3 \mathrm{P}$ samples. 


\section{$3 \cdot 3$ 母材およびFSW 攪拌部の機械的特性}

Fig.7 に各試料の母材と䚓找部における引張試験で得 られた公称応力一公称ひずみ曲線を示す。比較として SMA490AWの結果も併せて示す。各試料とも, 母材, $A_{3}$ 点 以上の攪拌部, $A_{1}$ 点以下の䚓拌部の順に強度が増加した。 また，0.1P材と $0.3 \mathrm{P}$ 材を比較すると，母材，摚拌部ともに $0.3 \mathrm{P}$ 材の方が強度が高い。微細粒からなる $A_{1}$ 点以下の筧找 部に打ける公称応力一公称ひずみ曲線においては，P量に かかわらず，比較的大きな降伏点伸びを示した。特に，比 較的一様な微細粒と微細セメンタイトから成る $0.1 \mathrm{P}$ 材に おいては，強度と延性のバランスに優れる特徴があるよう に見える。

Fig.8に各試料の母材と覮拌部における衝撃吸収エネル ギーの温度依存性を示す。Fig.8 (a) に示す 0.1P材に打いて は, DBTTが母材, $A_{3}$ 点以上の覮拌部, $A_{1}$ 点以下の筧找部 の順に低温側にシフトしており, $A_{1}$ 点以下の䚌找部は液体 窒素の温度でも脆性破壊せず，高い吸収エネルギーを示し た。Fig.8（b）に示す0.3P材に打いても, DBTTは同様に母 材, $A_{3}$ 点以上の覮找部, $A_{1}$ 点以下の覮挥部の順に低温側に シフトした。しかし，0.1P材と比較すると母材，覮找部と もにP量の増加により DBTTは高温側にシフトしている。 また, $0.1 \mathrm{P}$ 材と異なり, $0.3 \mathrm{P}$ 材の $A_{1}$ 点以下の攪挥部は約一 $180^{\circ} \mathrm{C}$ で脆性破壊した。

Fig.9に各試料の母材と䚓拌部の完全に脆性破壊した試 験片 (Fig.8の矢印) の破面を示す。母材については, 各試 料ともリバーパターンの観察されるへき開破面である。 $A_{3}$ 点以上の攪挥部は, $\mathrm{P}$ 量によらず, 母材よりも破面単位が 小さくなるという変化はあるが，同様のへき開破面を呈す る。一方で, $0.3 \mathrm{P}$ 材の $A_{1}$ 点以下の攪拌部では，様相が異な り, 一部の領域で約 $1 \mu \mathrm{m}$ 程度のサイズの粒界破面が観察 された (Fig.9 (e) の矢印)。な报, 0.1P 材は, 脆性破壊を示 さなかったので, 破面観察は行っていない。

\section{4. 考察}

\section{4・1 P量と接合性について}

FSWによる接合部断面マクロ写真（Fig.3）に示したよう に, 全ての試料打よび条件において接合部は無欠陥であっ た。溶融溶接性を著しく悪化するPを含有していても, 0.1 mass $\% \mathrm{C}$ 鋼において少なくとも 0.3 mass $\% \mathrm{P}$ まではFSWに よる接合が可能であることが示された。

$\mathrm{P}$ が溶融溶接性に悪影響を及ぼす原因は，主に凝固割れ を促進する点にある。凝固中の固液共存領域は, 凝固脆性 温度領域 (Brittleness Temperature Range: BTR) と呼ばれて おり延性が極めて低い。このときの延性を凝固収縮による 変位が上回ったときに凝固割れが発生する ${ }^{40)}$ 。P は凝固偏 析し，また結晶粒界に著しく偏析する結果，融点の低い液 膜を形成し，BTRを拡大させることにより，割れ発生の危
険性を高めることが知られている。Fig.2（b）に示す状態図 から明らかなように, 液相からの温度低下に伴いまず $\delta$ 相 が晶出し, その後 $\delta+\gamma+\mathrm{L}$ の三相共存状態を経た後, $\delta+$ $\gamma$ の二相共存状態となり凝固が完了する。しかし, 最終凝 固場所や結晶粒界ではPの濃化が著しく, 状態図から明ら かなように, P 濃度が極めて高くなると $\delta+\gamma+\mathrm{L}$ が安定て ある温度範囲が低温側まで拡大し，これが高温割れを引き 起こすことがわかる。一方, FSWでは融点以下の固相の温 度で接合できるので, 溶融溶接のような凝固偏析現象は起 こらず，無欠陥の接合部が得られたと考えられる。

また, Pは，溶融溶接において微細組織に影響を及ぼし 溶接部の勒性を低下させることが知られている ${ }^{41-43)}$ 。例え ば, 溶融溶接に扔いてPは未変態オーステナイトに打ける セメンタイトの析出を遅延させ, 勒性を悪化させる島状マ ルテンサイトの生成を促進すると報告されている ${ }^{41}$ 。一方 で, $A_{1}$ 点以下の FSW の擋找部では $\gamma$ 相への変態を伴わな いため, 島状マルテンサイトの形成は生じず，上記のよう な問題を防止できる。また $4 \cdot 3 \cdot 2$ 項で詳しく述べるよ うに, FSW の温度によらず䚓拌部の組織微細化による勒性 向上効果が期待できる。このように，高P鋼のFSW は接合 体の欠陥を防止できるだけでなく，接合体の特性向上にも 貢献すると考える。

\section{$4 \cdot 2$ 微細組織の形成機構について}

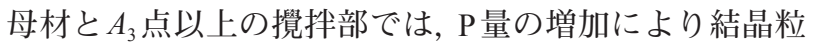
が微細化した (Figs.4, 5)。これはPのソリュート・ドラッ グ効果に起因すると推察する。Pはオーステナイト粒界, フェライト粒界のどちらにも偏析する元素として知られて いるが ${ }^{9-15,44)}$, 特にフェライトに比べて固溶限が低いオー ステナイトの粒界への偏析が顕著であると予想する。した がって，母材の熱処理，および $A_{3}$ 点以上の条件での FSWの 際に動的再結晶により形成されるオーステナイト粒は, P 量 の増加により微細化されると推察した。オーステナイト粒 径が Pにより微細化される結果，その後の冷却で得られた 組織も $\mathrm{P}$ 量の増加に伴い微細化する傾向を示したと考えた。

$A_{3}$ 点以上の攪挥部の組織に打いて, $\mathrm{P}$ 量の増加によりべ イナイトやマルテンサイトなどの低温変態生成物の量が減 少した (Fig.4)。一般に, Pはフェライト形成元素であり, $A_{3}$ 点を上昇させ，フェライトの生成を容易にする ${ }^{45,46)}$ 。し たがって, P量の増加に伴い, FSW 後の冷却中のフェライ 卜変態が促進されることが考えられる。さらに, 既に述べ たようにPはFSW中のオーステナイト粒径を小さくする 効果を有すると考えられ，フェライト変態が促進されるこ とが予想される。これらのPのフェライト変態促進効果に より, ベイナイトやマルテンサイトなどの低温変態生成物 を生成する未変態オーステナイト量が減少したと推察し た。一方では, Pは焼入れ性を高める元素としても知られ ている ${ }^{47)}$ 。以上のことを総合的に考慮すると, $\mathrm{P}$ 量の増加

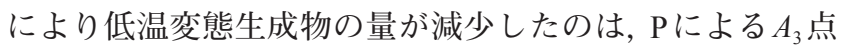


を上昇させる効果打よびオーステナイト粒径を微細化す る効果が, $\mathrm{P}$ 量増加による焼入れ性を増加させる効果を上 回ったためと推察した。

一方で, $A_{1}$ 点以下の覮挥部に打いては, $\mathrm{P}$ 量によらず共 通して微細フェライトと微細セメンタイトから成る組織が 得られた (Figs.4, 5)。これは, 低温でのFSWにより, フェ ライトは動的再結晶して著しく微細化し, 一方母材に存在 したパーライトは破砕し微細に分散したためと考える。し かし，0.3P材の方が $0.1 \mathrm{P}$ 材よりフェライト粒径が大きく， またbimodalなフェライト組織を呈したことは特筆され る。上に述べたように, $0.3 \mathrm{P}$ 材の $A_{3}$ 点以上の温度で FSW し た攪挥部においては, 低温变態生成物の量が $0.1 \mathrm{P}$ 材より少 なかった。同様のことが，母材に打けるフェライトとパー ライト組織のパーライト量についてもいえる。すなわち, $0.3 \mathrm{P}$ 材の方が，0.1P材より少ないことが予想される。この ことは, Fig.4に打いて認められる。一般的に, フェライト とパーライトから成る母材を $A_{1}$ 点以下の温度でFSWを施 すと, パーライトを含む領域での動的再結晶粒の核生成 頻度は, フェライトの領域でのそれより大きく, パーライ 卜を含む領域で微細化が著しくなることが予想される。そ の結果，母材のパーライト量が少ない $0.3 \mathrm{P}$ 材の方が，むし ろ粒径が大きくなったと考えた。また，0.3P材では母材の パーライト量が少なく不均一性が高いため, bimodal組織 が顕著になったと推察される。

\section{$4 \cdot 3$ 機械的特性について}

$4 \cdot 3 \cdot 1$ 強度と延性

$A_{3}$ 点以上の覮挥部の公称応力一公称ひずみ曲線は, $0.1 \mathrm{P}$ 材と $0.3 \mathrm{P}$ 材とで若干異なる挙動を示し, $0.1 \mathrm{P}$ 材では連続降 伏の，一方 $0.3 \mathrm{P}$ 材では不連続降伏の様相を示す。これは, 0.1P材, 0.3P材の微細組織におけるべイナイトやマルテン サイトなどの低温変態生成物量に起因すると考えられる。 $\mathrm{DP}$ 鋼のような，フェライト組織にマルテンサイトなどの 低温変態生成物が存在する鋼では, 両組織の界面に可動転 位が存在するため連続降伏が発現することが知られてい る ${ }^{48)}$ 。0.1P材は, これらの低温変態生成物量が多いため界 面転位の密度が増し連続降伏の様相を示し, 一方 $0.3 \mathrm{P}$ 材で はマルテンサイトが存在するものの極めて少量であるため 不連続降伏の様相を示したと推察される。また, $0.1 \mathrm{P}$ 材の 破断伸びは，0.3P材と比較して低いが，これもべイナイト やマルテンサイトの量が多いためと考えられる。

$A_{1}$ 点以下の覮拌部は, $0.1 \mathrm{P}$ 材, 0.3P材どちらにおいても 母材や $A_{3}$ 点以上の擤拌部と比較して高い強度を示し, 特 に0.1P材においては延性も良好であり, 優れた強度-延性 バランスが示された。 $A_{1}$ 点以下の䚓挥部における降伏応力 は，母材と比較して $0.1 \mathrm{P}$ 材では $394 \mathrm{MPa}, 0.3 \mathrm{P}$ 材では 353 MPa向上した。降伏強度と結晶粒径との間にはHall-Petch の関係が成り立ち, 結晶粒の微細化に伴い降伏強度が増加 することはよく知られており ${ }^{49-51)}, A_{1}$ 点以下の㹂挥部にお
ける強度の向上は主に結晶粒微細化に起因すると考えら れる。また, $0.1 \mathrm{P}$ 材, 0.3P材ともに明確な降伏点伸びが確 認された。降伏点伸びは細粒組織によく見られる現象であ り, 結晶粒径の微細化に伴い発現し, 増加することが報告 されている ${ }^{52-55)}$ 。 $A_{1}$ 点以下の攪挥部の試料で共通して降伏 点伸びが見られたのは，いずれも微細粒のためと考える。 その中でも, 0.1P材に打いて, 0.3P材と比較して降伏点伸 びが大きいのは, 結晶粒径がより小さいことに起因すると 考えられる。また, 0.1P材については $0.3 \mathrm{P}$ 材と比較して局 部伸びが良好である。細粒化により絞りが向上することが 報告されており ${ }^{56)}, 0.1 \mathrm{P}$ 材の $A_{1}$ 点以下の筧拌部においても 細粒化により局部伸びが向上したと考えられる。一方で, $0.3 \mathrm{P}$ 材の局部伸びは $0.1 \mathrm{P}$ 材と比較して小さい。このように $0.3 \mathrm{P}$ 材の $A_{1}$ 点以下の攪挥部で局部伸びが小さいのは, $0.3 \mathrm{P}$ 材の方が平均粒径が大きいことに加え, Bimodal組織であ ることに起因すると考える。すなわち, 0.3P材の Bimodal 組織に打いては，粒径の大きな弱い部分にひずみが集中 し, 局部伸びが低下したことも推察される。

$4 \cdot 3 \cdot 2$ 勒性

0.1P, 0.3P材ともに, 攪挥部では母材と比べてDBTTが低 温側にシフトした。特に, $A_{1}$ 点以下の覮找部では, $0.1 \mathrm{P}$ 材 では液体窒素の温度でも脆性破壊せず, $0.3 \mathrm{P}$ 材ではDBTT がー $175^{\circ} \mathrm{C}$ であった。このように $A_{1}$ 点以下の攪找部で著し く勒性が向上したことの主な要因として, 結晶粒微細化 が挙げられる。Fig.10に0.1P材, 0.3P 材の母材と攪挥部に 打ける結晶粒径 $d$ と延性-脆性遷移温度 (DBTT) の関係を 示している。比較として, 既に報告されている C-Mn 鋼 ${ }^{57)}$, $\mathrm{C}-\mathrm{Mn}-\mathrm{Nb}$ 鋼 $^{58)}$ 抢よびIF 鋼 ${ }^{14)}$ の結果も併せて示す。0.1P材

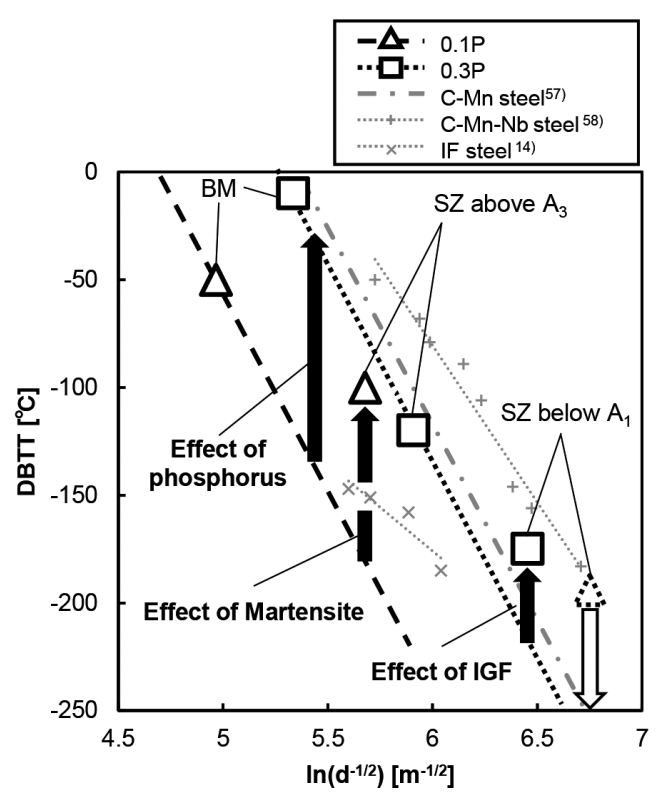

Fig. 10. Effect of grain diameter on ductile-to-brittle transition temperature of base materials and stir zones for $0.1 \mathrm{P}$ and $0.3 \mathrm{P}$ samples; BM: base material, SZ: stir zone, IGF: intergranular fracture; Data of C-Mn-stee ${ }^{57)}$, $\mathrm{C}-\mathrm{Mn}-\mathrm{Nb}$ steel $^{58)}$ and IF steel ${ }^{14)}$ are superimposed. 
と $0.3 \mathrm{P}$ 材の直線の傾きは, $\mathrm{C}$ 量がおおよそ同程度である $\mathrm{C}-\mathrm{Mn}$ 鋼 $(0.15 \mathrm{C}-1.5 \mathrm{Mn}$ [mass\%]) と等しいと仮定した。0.1P 材の $A_{3}$ 点以上の攪拌部の DBTT は, 直線よりも高温側に位 置する。これは, $A_{3}$ 点以上の攪拌部においては, $1 \mu \mathrm{m}$ 以上 の粗大なマルテンサイトが存在することに起因すると推察 される（Fig.4）。また，0.3P材の $A_{1}$ 点以下の攪拌部の DBTT も直線よりもわずかに高温側に位置する。これは，0.3P材 の $A_{1}$ 点以下の覮拌部においては, DBTTよりも低温側の脆 化域で粒界破壊が示されたことから，粒界脆化に起因する ものと推察される (Fig.9)。以上のように, DBTTは微細組 織や破壊形態の影響は受けるものの，0.1P材，0.3P材とも に結晶粒微細化に伴い勒性が向上した。その結果，0.3P材 の $A_{1}$ 点以下の攪拌部の DBTTが，P量が 0.01 mass $\%$ まで低 減されたSMA490AWよりも低い温度となった点は，高 $\mathrm{P}$ 添加による脆化を結晶粒微細化により克服できることを示 しており，特筆に值する。

また, Fig.10において $0.1 \mathrm{P}$ 材と $0.3 \mathrm{P}$ 材の結晶粒径 $d$ が等 しいときのDBTTの差がPの影響を示していると考えら れる。 $\mathrm{P}$ 量 0.2 mass\%の増加で DBTT は $115^{\circ} \mathrm{C}$ 高温側にシフ トした。Suzuki らは, Fe-C-Pの三元型合金 $(0.04$ mass\%C) に打いて，P量0.11 mass\%から 0.34 mass\%までの増加で, $\mathrm{DBTT}$ が約 $55^{\circ} \mathrm{C}$ 高温側へシフトすることを示した ${ }^{10)}$ 。この ように, P量の増加による DBTTの変化量は，本研究では Suzuki らの報告に比べて大きくなった。C量，硬質第二相 および結晶粒径などがその要因として考えられるが，詳細 は今後の課題としたい。

$A_{1}$ 点以下の FSWで，0.3P材は脆化域で粒界破壊を示し た (Fig.9 (e))。破面単位から判断すると，フェライト粒界 での破壊であると推察され，0.3P材の $A_{1}$ 点以下の攪挥部で は，粒界破壊強度がへき開破壊強度より低いことを示して いる。その原因として $A_{1}$ 点以下で FSWを行った時のPの 粒界偏析量の増加が考えられる。

一般的に, $A_{1}$ 点以下の攪拌部で得られるような動的再結 晶フェライトは, フレッシュな粒界を持ち, 形成された直 後はPの偏析は無いと考えられる。また, 冷却中のPの粒 界偏析も，通常のPの拡散では困難であると推察される。 一方では, FSWによる $A_{1}$ 点以下での強加工時に, 動的な $\mathrm{P}$ の粒界偏析が生じる可能性もある。高温で変形を加えるこ とにより，平衡状態よりも過㮃にPが粒界偏析するといっ た報告が数多くある ${ }^{59-62)}$ 。変形が特に $A_{1}$ 点以下の温度で 加わると，粒内に過飽和の空孔が発生し，それらの空孔が 過飽和状態の不純物と結びついた複合体を形成し，粒内と 粒界の間に複合体の濃度勾配ができ，複合体が粒界に移動 し，不純物が粒界に短時間のうちに偏析すると考えられて いる。このような動的な粒界偏析は,ひずみ速度の増加に 伴い増えることも報告されている ${ }^{62)}$ 。したがって，材料流 動を伴い多量のひずみが導入される FSWでは，上記のよ うな動的な粒界偏析が起こっていることが推察される。こ
れを実証するためには粒界偏析を実測する必要があり，今 後の課題としたい。

\section{5. 結言}

溶融溶接が不可能な，P量を 0.1-0.3 mass\%に増量した 0.1 mass $\% \mathrm{C}$ の高 $\mathrm{P}$ 耐候性鋼を作製し，FSWした時の接合性， 組織の発達および機械的特性を調査し, 以下の知見を得 た。

(1) $A_{3}$ 点以上および $A_{1}$ 点以下の FSW ともに, 接合部は無欠 陷であった。FSWは固相接合であり，溶融溶接におけ る欠陷発生の原因となる凝固を伴わないことに起因す ると考えた。FSWでは, 少なくとも 0.3 mass\%P鋼まで は接合可能であることが明らかとなった。

(2) FSW 攪找部の結晶粒は母材より微細化し, 特に $A_{1}$ 点以 下のFSWに拀いてその傾向は著しい。結晶粒の微細化 に伴い, DBTTは低温側へシフトした。0.3P材の $A_{1}$ 点以 下の覮挥部 $(\sim 2 \mu \mathrm{m})$ の DBTTは母材 $(\sim 23 \mu \mathrm{m})$ より， 約 $150^{\circ} \mathrm{C}$ 低温側にシフトした。P量の増加による脆化 は，結晶粒の微細化により克服できることが明らかと なった。

(3) $\mathrm{P}$ 量の増加に伴い, 母材および $A_{3}$ 点以上の攪挥部は細 粒化した。Pのソリュート・ドラッグ効果が原因と考え た。一方， $A_{1}$ 点以下の攪拌部は微細であるが，0.3P材の 方が粒径は大きく, Bimodal組織を示した。これは，母 材におけるパーライト量が $0.3 \mathrm{P}$ 材の方が少なく, FSW 中のフェライトの動的再結晶核の生成頻度が低く，ま た不均一であるためと考えた。

(4) $\mathrm{P}$ 量によらず母材と $A_{3}$ 点以上の攪拌部では脆性破壊形 態はへき開破壊であるのに対し, $0.3 \mathrm{P}$ 材の $A_{1}$ 点以下の 攪拌部では粒界破壊であった。 $A_{1}$ 点以下の攪拌部では, 超強加工の FSW 中に動的再結晶に伴うフェライト粒界 へのPの動的偏析が生じるため粒界破壊が生じたと推 察した。

\section{謝辞}

この成果の一部は, 国立研究開発法人科学技術振興 機構の未来社会創造事業，科学研究費補助金 (基盤 $\mathrm{A}$ : 19H00826）および一般社団法人鉄鋼協会の研究会 IIにおい て得られたものです。また，研究にあたってご助言いただ いた大阪大学大学院工学研究科 大畑充教授に感謝いたし ます。

\section{文献}

1 ) T.Hosaka, T.Kusunoki and J.Kato: Bridge Found. Eng., 36(2002), 31 (in Japanese).

2 ) T.Misawa, T.Kyuno, W.Suëtaka and S.Shimodaira: Corros. Sci., 11(1971), 35. https://doi.org/10.1016/S0010-938X(71)80072-0

3 ) H.Kihira, S.Ito and T.Murata: Corros.Sci., 31(1990), 383. https://doi. 
org/10.1016/0010-938X(90)90135-R

4) P.Dillmann, R.Balasubramaniam and G.Beranger: Corros. Sci., 44(2002), 2231. https://doi.org/10.1016/S0010-938X(02)00028-8

$5)$ R.Balasubramaniam and A.V.Ramesh Kumar: Corros. Sci., 45(2003), 2451. https://doi.org/10.1016/S0010-938X(03)00074-X

6) B.K.Jena, N.Gupta, B.Singh and G.Sahoo: J. Met. Mater. Miner., 24(2014), 1.

7 ) K.Sakata, K.Okuda and O.Furukimi: Tetsu-to-Hagané, 84(1998), 566 (in Japanese). https://doi.org/10.2355/tetsutohagane1955.84.8_566

8) N.Nakada, M.Fujihara, T.Tsuchiyama and S.Takaki: ISIJ Int., 51(2011), 1169. https://doi.org/10.2355/isijinternational.51.1169

9) K.Abiko, S.Suzuki and H.Kimura: Trans. Jpn. Inst. Met., 23(1982), 43. https://doi.org/10.2320/matertrans 1960.23 .43

10) S.Suzuki, M.Obata, K.Abiko and H.Kimura: Tetsu-to-Hagané, 70(1984), 2262 (in Japanese). https://doi.org/10.2355/tetsutohagane 1955.70.16_2262

11) H.Kimura: Tetsu-to-Hagané, 79(1993), N754 (in Japanese). https:// doi.org/10.2355/tetsutohagane1955.79.11_N754

12) K.Abiko: Materia Jpn., 33(1994), 11 (in Japanese). https://doi.org/ 10.2320/materia.33.11

13) M.Hashimoto, Y.Ishida, S.Wakayama, R.Yamamoto, M.Doyama and T.Fujiwara: Acta Metall., 32(1984), 13. https://doi.org/10.1016/00016160(84)90196-2

14) N.Tsuji, S.Okuno, Y.Koizumi and Y.Minamino: Mater. Trans., 45(2004), 2272. https://doi.org/10.2320/matertrans.45.2272

15) M.Yamaguchi: J. Jpn. Inst. Met., 72(2008), 657 (in Japanese). https:// doi.org/10.2320/jinstmet.72.657

16) M.Jafari and K.Tsuzaki: J. Alloy. Compd., 557(2013), S636. https:// doi.org/10.1016/j.jallcom.2012.03.031

17) F.Matsuda: J. Jpn. Weld. Soc., 36(1967), 973 (in Japanese). https:// doi.org/10.2207/qjiws1943.36.973

18) F.Matsuda, H.Kita, T.Nakazaki, Y.Akutsu, T.Uehara and T.Shida: $Q$. J. Jpn. Weld. Soc., 4(1986), 79 (in Japanese). https://doi.org/10.2207/ qjjws.4.79

19) F.Matsuda and T.Ueyama: Q. J. Jpn. Weld. Soc., 11(1993), 95 (in Japanese). https://doi.org/10.2207/qijws. 11.95

20) K.Tamaki, H.Kawakami and J.Suzuki: Q. J. Jpn. Weld. Soc., 20(2002), 266 (in Japanese). https://doi.org/10.2207/qijws.20.266

21) K.Hosoi and N.Hara: J. Jpn. Weld. Soc., 78(2009), 555 (in Japanese). https://doi.org/10.2207/jjws.78.555

22) JIS G 3114: 2016, Hot-rolled atmospheric corrosion resisting steels for welded structure (in Japanese).

23) JIS G 3125: 2015, Superior atmospheric corrosion resisting rolled steels (in Japanese).

24) H.Mori, M.Noda and T.Tominaga: J. Jpn. Inst. Light Met., 57(2007), 506 (in Japanese). https://doi.org/10.2464/jilm.57.506

25) H.Takehisa: J. Jpn. Inst. Light Met., 56(2006), 178 (in Japanese). https://doi.org/10.2464/jilm.56.178

26) K.Nara: J. Jpn. Weld. Soc., 82(2013), 177 (in Japanese). https://doi. org/10.2207/jjws.82.177

27) K.Ohishi and H.Fujii: Materia Jpn., 53(2014), 603 (in Japanese). https://doi.org/10.2320/materia.53.603

28) W.M.Thomas, P.L.Threadgill and E.D.Nicholas: Sci. Technol. Weld. Join., 4(1999), 365. https://doi.org/10.1179/136217199101538012

29) T.J.Lienert, W.L.Stellwag, Jr., B.B.Grimmett and R.W.Warke: Weld. $J ., 82(2003), 1-S$.

30) A.P.Reynolds, W.Tang, M.Posada and J.DeLoach: Sci. Technol. Weld. Join., 8(2003), 455. https://doi.org/10.1179/136217103225009125

31) H.Fujii, L.Cui, N.Tsuji, M.Maeda, K.Nakata and K.Nogi: Mater. Sci. Eng. A, 429(2006), 50. https://doi.org/10.1016/j.msea.2006.04.118

32) L.Cui, H.Fujii, N.Tsuji and K.Nogi: Scr. Mater, 56(2007), 637. https://doi.org/10.1016/j.scriptamat.2006.12.004

33) Y.S.Sato, H.Yamanoi, H, Kokawa and T.Furuhara: Scr. Mater, 57(2007), 557. https://doi.org/10.1016/j.scriptamat.2007.04.050
34) Y.S.Sato, T.W.Nelson, C.J.Sterling, R.J.Steel and C.-O.Pattersson: Mater. Sci. Eng. A, 397(2005), 376. https://doi.org/10.1016/j.msea. 2005.02.054

35) M.Maki: Tekkou no Soshiki Seigyo -Sono Genri to Houhou (Microstructure Control in Steels -Principle and Method), Uchida Roukakuho, Tokyo, (2015) (in Japanese).

36) T.Tanaka: Bull. Jpn. Inst. Met., 17(1978), 104 (in Japanese). https:// doi.org/10.2320/materia1962.17.104

37) T.Maki: Bull. Jpn. Inst. Met., 27(1988), 623 (in Japanese). https://doi. org/10.2320/materia1962.27.623

38) D.H.Shin, B.C.Kim, Y.-S.Kim and K.-T.Park: Acta Mater., 48(2000), 2247. https://doi.org/10.1016/S1359-6454(00)00028-8

39) N.Tsuji, Y.Saito, H.Utsunomiya and S.Tanigawa: Scr. Mater., 40(1999), 795. https://doi.org/10.1016/S1359-6462(99)00015-9

40) K.Shinozaki: J. Jpn. Weld. Soc., 71(2002), 455 (in Japanese). https:// doi.org/10.2207/qjjws1943.71.455

41) F.Matsuda, K.Ikeuchi, Y.Fukuda, Y.Horii, H.Okuda, T.Shiwaku, C.Shiga and S.Suzuki: Trans. JWRI, 24(1995), 1.

42) R.Uemori, N.Saito, S.Aihara and H.Mabuchi: CAMP-ISIJ, 9(1996), 1190 (in Japanese).

43) T.Yokota, K.Hase, K.Yamada and I.Ohnuma: CAMP-ISIJ, 24(2011), 325, CD-ROM (in Japanese).

44) T.Abe, K.Tsukada and I.Kozasu: Tetsu-to-Hagané, 70(1984), S1261 (in Japanese). https://doi.org/10.2355/tetsutohagane1955.70.13_S1223

45) K.W.Andrews: J. Iron Steel Inst., 203(1965), 721.

46) K.Sato, Y.Kokabu and K.Matsukura: Tetsu-to-Hagané, 58(1972), S486 (in Japanese). https://doi.org/10.2355/tetsutohagane1955.58.11_ S479

47) I.Tanaka, H.Izumi and S.Isa: Tekkou Zairyogaku (Metallurgy of Steels), Asakura Publishing, Tokyo, (1981) (in Japanese).

48) I.Tsukatani and M.Sudo: Tetsu-to-Hagané, 72(1986), 85 (in Japanese). https://doi.org/10.2355/tetsutohagane1955.72.1_85

49) N.Hansen: Scr. Mater., 51(2004), 801. https://doi.org/10.1016/j. scriptamat.2004.06.002

50) S.Takaki: Mater. Sci. Forum., 706-709(2012), 181. https://doi. org/10. 4028/www.scientific.net/MSF.706-709.181

51) M.Etou, S.Fukushima, T.Sasaki, Y.Haraguchi, K.Miyata, M.Wakita, T.Tomida, N.Imai, M.Yoshida and Y.Okada: ISIJ Int., 48(2008), 1142. https://doi.org/10.2355/isijinternational.48.1142

52) N.Tsuchida, Y.Tomota and K.Nagai: Tetsu-to-Hagané, 89(2003), 1170 (in Japanese). https://doi.org/10.2355/tetsutohagane1955.89.11_1170

53) Y.Tomota, A.Narui and N.Tsuchida: ISIJ Int., 48(2008), 1107. https:// doi.org/10.2355/isijinternational.48.1107

54) S.Gao, M.Chen, S.Chen, N.Kamikawa, A.Shibata and N.Tsuji: Mater. Trans., 55(2014), 73. https://doi.org/10.2320/matertrans.MA201317

55) M.H.Park and N.Tsuji: CAMP-ISIJ, 31(2018), 832, CD-ROM (in Japanese).

56) W.B.Morrison and R.L.Miller: Proc. 16th Sagamore Army Materials Research Conf., ed by J.J. Burke and V. Weiss, Syracuse University Press, Syracuse, NY, (1969), 183.

57) T.Hanamura, M.-C.Zhao, H.Qiu, F.Yin and K.Nagai: Tetsu-to-Hagané, 95(2009), 71 (in Japanese). https://doi.org/10.2355/tetsutohagane.95. 71

58) A.A.Howe: Mater. Sci. Technol., 16(2000), 1264. https://doi.org/ 10.1179/026708300101507488

59) H.Suto and K.Sato: J. Jpn. Inst. Met., 41(1977), 458 (in Japanese). https://doi.org/10.2320/jinstmet1952.41.5_458

60) T.Xu: J. Mater. Sci., 35(2000), 5621. https://doi.org/10.1023/ A: 1004877601914

61) S.-H.Song, Q.Zhang and L.-Q.Weng: Mater. Sci. Eng. A, 473(2008), 226. https://doi.org/10.1016/j.msea.2007.04.007

62) X.-M.Chen and S.-H.Song: Mater. Sci. Eng. A, 527(2010), 7580. https://doi.org/10.1016/j.msea.2010.08.054 